\title{
Influence of leafy spurge on forage utilization by cattle
}

\author{
DAVID G. HEIN AND STEPHEN D. MILLER
}

Former graduate student (now Director, Billings Institute of Religion, Billings, Montana 59101); and professor, Weed Science, P.O. Box 3354, University of Wyoming, Laramie 82071.

\begin{abstract}
A 3-year field study was conducted near Grassrange, Montana. (Latitude $46^{\circ} 50 \mathrm{~N}$ and Longitude $108^{\circ} 50^{\prime} \mathrm{W}$ ) to determine the effect of leafy spurge (Euphorbia esula L.) shoot density, control, and canopy cover on the utilization of forage by cattle. Picloram (4-amino-3,5,6-trichloro-2-pyridinecarboxylic acid) was applied at 0.28 to $2.24 \mathrm{~kg}$ ae/ha on leafy spurge-infested native pasture to establish different levels of leafy spurge shoot density and canopy cover. Utilization of forage was influenced by leafy spurge shoot density $(r=-0.65)$ and canopy cover $(r=0.87)$ and was not related to the amount of forage $(r=-0.1)$ produced. A leafy spurge canopy cover of $10 \%$ or more and a leafy spurge shoot control value of $90 \%$ or less resulted in a significant decrease in utilization of forage by cattle.
\end{abstract}

Key Words: Euphorbia esula L., picloram, grazing management, range improvement

Leafy spurge (Euphorbia esula L.) is a long-lived perennial weed estimated to infest over 1 million hectares of pasture and rangeland in the Northern Great Plains and Rocky Mountain regions of the United States (Dunn 1979). Leafy spurge is classified as a poisonous plant which produces an irritant causing dermatitis to man and animals (Kingsbury 1964).

Most research indicates that sheep can consume significant amounts of leafy spurge with no adverse effects (Christensen et al. 1938, Landgraf et al. 1984, and Bartz et al. 1985). Only a single case of poisoning of sheep attributed to consumption of leafy spurge plants appears in the literature (Johnston and Peake 1960). However, leafy spurge adversely influences forage utilization by cattle. Given free-choice grazing, cattle avoid forage in areas heavily infested with leafy spurge (Lym and Kirby 1987). Cattle and forage production losses due to leafy spurge infestations have been estimated at over $\$ 12$ million annually in North Dakota (Messersmith and Lym 1983).

The purpose of this research was to determine (a) the influence of leafy spurge shoot density, control, and canopy cover on forage utilization by cattle; (b) the effect of forage production on utilization; and (c) the level of leafy spurge control or canopy cover that is required to maintain optimum forage utilization.

\section{Methods and Materials}

The response of leafy spurge to single picloram treatments was evaluated at the 5E Ranch near Grassrange, Montana (Latitude $46^{\circ} 50^{\prime} \mathrm{W}$ and Longitude $108^{\circ} 50^{\prime} \mathrm{W}$ ) during the 1986 and 1987 growing seasons. The sandy clay loam soil on the test site was a fine, mixed Udic Haploboroll of the Loken series with $3.5 \%$ organic matter, $7.0 \mathrm{pH}$ and an average depth of $56 \mathrm{~cm}$.

Published with the approval of the Director, Wyoming Agricultural Experiment Station as Journal Article 1654 . This project was partially financed by the Wyoming Department of Agriculture.

Manuscript accepted 24 Oct. 1990.
Plots were located within a 160 -ha cool-season native grass, fenced pasture. Leafy spurge had been established on this site since the mid 1920 's. During the past 25 years the site has been grazed by cattle for 6 to 8 weeks in late spring or early summer at low to moderate stocking rates ( 2 to $4 \mathrm{AUM} / \mathrm{ha}$ ). Grasses at the site included bluebunch wheatgrass (Agropyron spicatum (Pursh) Scribn. and Smith), slender wheatgrass (Agropyron trachycaulum (Link) Malte var. trachycaulum), desert wheatgrass (Agropyron desertorum (Fisch.) Schult), prairie Junegrass (Koeleria cristata (L.) Pers.), needle-and-thread (Stipa comata Trin. and Rupr.) and Kentucky bluegrass (Poa pratensis L.).

Herbicide treatments were applied with a tractor-mounted boom sprayer delivering $280 \mathrm{~L} /$ ha at $275 \mathrm{kPa}$. Herbicide treatments were applied on 16 May 1985 when the leafy spurge plants were 10 to $40 \mathrm{~cm}$ in height and in the early bud to mid-flowering stage of inflorescence development.

The $5 \times 29-\mathrm{m}$ research plots, were arranged in a randomized complete block design with 4 replications. Exclosure fences were constructed to divide each plot into 2 equal subplots. This provided an area for grazing and nongrazing on each plot. Exclosure fences were removed in the fall after the collection of production data. The placement of exclosures was alternated each year so that a subplot subjected to grazing one year was not grazed the next year.

Data were analyzed using a randomized complete block design and/or a randomized complete block design with a split block arrangement. Fisher's protected LSD at the 0.05 level of significance was used to determine mean separation. Pearson productmoment correlation coefficient values were based on individual observations within experimental units. Significance level for correlations was 0.001 unless otherwise stated. There was no significant interaction between grazing and treatment on leafy spurge shoot density, control, or canopy cover so the data were combined over the 2 subplots.

Leafy spurge shoot density was determined in four $0.25-\mathrm{m}^{2}$ permanent density sampling sites located in each plot. The number of sampling sites was based on Pieper's (1978) sample size estimation technique. All uninjured leafy spurge shoots were counted in May and percentage control based on pre- and post-treatment shoot counts. Live leafy spurge canopy cover was determined with a 10-pin vertical point frame. A metered tape was stretched diagonally through each plot and 10 permanent observations made at points along the tape. Each year a total of 100 data points per plot were taken at the same sites along the diagonal transect. Percent canopy of leafy spurge, grasses, and forbs was determined from the data collected.

Vegetation samples were harvested in August of each year using a commercial, electric hedge trimmer with a portable generator. Four randomly located $0.5-\mathrm{m}^{2}$ samples were harvested in each of the 64 field plots. Vegetation was dried, separated into leafy spurge, grasses, and forbs, and weighed. The term forage production used in this study refers to the dry matter weight of grasses 
only. Forbs accounted for less than $1 \%$ of the total production and were excluded from production data.

Utilization percentages were calculated by comparing grazed and ungrazed production within the same treatment plot. Utilization includes all usage of forage, i.e., natural disappearance, rodent, wildlife, insect, and cattle consumption. The research site was fenced to provide a 5-ha pasture with 3 gates for access of cattle into the area. Cow-calf grazing was permitted in the study area until utilization on leafy spurge-free plots reached $50 \%$. The season of use began on 1 June and extended for 6 to 8 weeks and was terminated when maximum potential $(50 \%)$ utilization was reached. The stocking rate averaged $2 \mathrm{AUM} /$ ha throughout the grazing season.

Normal annual precipitation at the site is $40 \mathrm{~cm}$ with $20 \mathrm{~cm}$ falling during the 3 months of data collection (15 May to 15 Aug.). Rainfall during the months of data collection was 15,12 , and $23 \mathrm{~cm}$ in 1985,1986 , and 1987 , respectively.

\section{Results and Discussion}

Data were collected at the field site in both 1986 and 1987 following picloram application in May 1985. Only data from 1987 are presented because a grasshopper (Melanoplus differtialis Thomas) outbreak in 1986 significantly impacted utilization. Grasshopper populations throughout the area were extremely high ( 28 to 30 hoppers $/ \mathrm{m}^{2}$ ) and resulted in substantial consumption of both forage grass and leafy spurge.

Leafy spurge shoot density influenced forage utilization by cattle (Table 1). For example, the untreated control averaged 405 leafy

Table 1. Leafy spurge shoot density, control and canopy cover or forage production and utilization in 1987 following single picloram treatments in 1985.

\begin{tabular}{|c|c|c|c|c|c|}
\hline \multirow[b]{2}{*}{ Picloram $^{\mathrm{a}}$} & \multicolumn{3}{|c|}{ Leafy spurge } & \multicolumn{2}{|c|}{ Forage } \\
\hline & $\begin{array}{l}\text { Shoot } \\
\text { density }\end{array}$ & Control & $\begin{array}{l}\text { Canopy } \\
\text { cover }\end{array}$ & $\begin{array}{l}\text { Prod- } \\
\text { duction }\end{array}$ & $\begin{array}{l}\text { Utiliz- } \\
\text { ation }\end{array}$ \\
\hline$\overline{(\mathrm{kg} / \mathrm{ha})}$ & $\left(\mathrm{no} / \mathrm{m}^{2}\right)$ & $\ldots \ldots(\%)$ & $-\ldots \ldots$ & (kg/ha) & $-\ldots(\%)-\ldots$ \\
\hline 0.00 & 405 & 0 & 43 & 500 & 0 \\
\hline 0.28 & 275 & 15 & 50 & 1000 & 5 \\
\hline 0.56 & 265 & 17 & 38 & 1090 & 0 \\
\hline 0.84 & 185 & 46 & 30 & 1570 & 28 \\
\hline 1.12 & 120 & 76 & 9 & 1760 & 44 \\
\hline 1.68 & 25 & 92 & 6 & 1660 & 48 \\
\hline 2.24 & 10 & 97 & 1 & 1780 & 52 \\
\hline $\begin{array}{l}\text { L.S.D. } \\
(0.05)\end{array}$ & 235 & 13 & 16 & 730 & 18 \\
\hline C.V. (\%) & 86 & 18 & 44 & 37 & 47 \\
\hline
\end{tabular}

Treatments applied 16 May 1985.

spurge shoots $/ \mathrm{m}^{2}$ and yielded $0 \%$ utilization while the plots treated with $2.24 \mathrm{~kg} /$ ha picloram averaged 10 leafy spurge shoots $/ \mathrm{m}^{2}$ and $52 \%$ utilization. The correlation between leafy spurge shoot density and forage utilization was negative $(r=0.65)$ while percent control of leafy spurge shoots and forage utilization were positively correlated $(r=0.90)$ among single picloram treatments.

Leafy spurge shoot control 1 year following treatment averaged $43,74,83,97,98$, and $99 \%$ when picloram was applied at $0.28,0.56$, $0.84,1.12,1.68$, and $2.24 \mathrm{~kg} / \mathrm{ha}$, respectively (data not shown in table). Leafy spurge shoot control declined an average of $36 \%$ the second year following applications of picloram at $1.12 \mathrm{~kg} / \mathrm{ha}$ or less (Table 1), which is similar to previously published results (Alley et al. 1982, Lym and Messersmith 1985).

As leafy spurge canopy cover increased, forage utilization decreased (Table 1). Application of $2.24 \mathrm{~kg} /$ ha picloram in 1985 reduced leafy spurge canopy cover to $1 \%$ in 1987 and resulted in $52 \%$ utilization of forage by cattle. This can be contrasted with the
0.28 and $0.56 \mathrm{~kg} /$ ha picloram treatments also applied in May 1985 which resulted in leafy spurge canopy cover values of 50 and $38 \%$ and forage utilization values of 5 and $0 \%$, respectively. The high negative correlation $(r=-0.87)$ suggests a strong relationship between leafy spurge canopy cover and forage utilization.

Picloram applied at rates exceeding $0.56 \mathrm{~kg} /$ ha reduced leafy spurge canopy cover and increased forage production (Table 1). Although forage production was not statistically different among treatments receiving more than $0.56 \mathrm{~kg}$ / ha picloram, utilization values were significantly different. Forage production and forage utilization were not correlated $(r=-0.1)$ when comparing experimental units with similar leafy spurge densities and canopy cover but with different production. This suggests that utilization was not influenced by forage production. These data support field observations that the grazing behavior of cattle is influenced by leafy spurge shoot density and canopy cover rather than by the amount of forage grass present. Thus a leafy spurge-infested pasture may yield $1,000 \mathrm{~kg} /$ ha of forage grass, but have little or no utilization by cattle because of the deterrent effect of leafy spurge.

Leafy spurge shoot density and canopy cover exerted the greatest influence on utilization of forage grasses by cattle. Canopy cover of leafy spurge is relatively simple to estimate and provides the landowner with an excellent tool to assist in a grazing management program. At a level of $10 \%$ leafy spurge canopy cover, forage utilization was approximately $45 \%$ (Fig. 1). As leafy spurge canopy

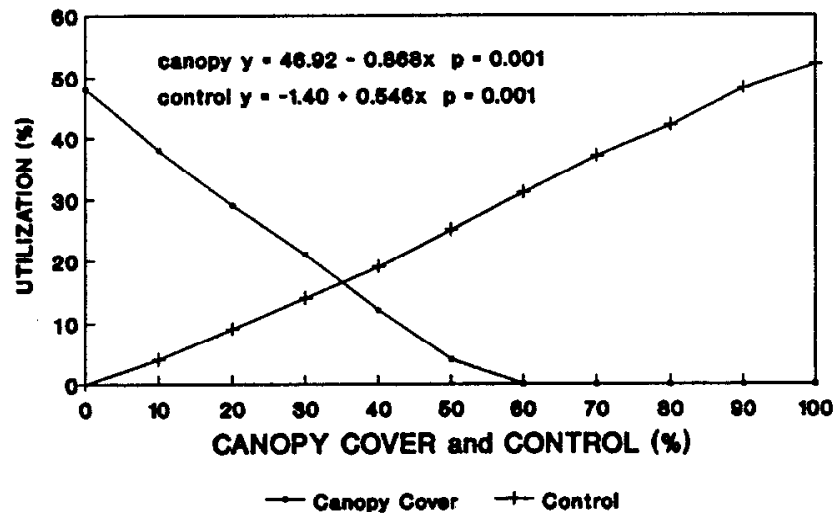

Fig. 1. The influence of leafy spurge canopy cover and control on forage utilization by cattle.

cover increased above $10 \%$, forage utilization declined rapidly. Therefore, to achieve $50 \%$ forage utilization by cattle, the level of leafy spurge canopy cover must be less than $10 \%$. When leafy spurge shoot control was $90 \%$ or more, forage utilization approached $50 \%$. A rapid decrease in utilization occurred when control dropped below $90 \%$. Thus, assuming a desired forage utilization of 50\%, the level of leafy spurge shoot control must be $90 \%$ or more.

A control program is necessary to reduce leafy spurge populations sufficiently to allow proper utilization of forage grasses. Otherwise, valuable forage grasses in pastures with moderate to high leafy spurge infestations will not be utilized. Cattle appear to be deterred from grazing in leafy spurge infested areas because of the latex content of leafy spurge (Lym and Kirby 1987). This model can be used to predict forage utilization by cattle in leafy spurgeinfested pasture.

\section{Literature Cited}

Alley, H.P., R.E. Vore, and T.D. Whitson. 1982. A summary of original and three repetitive herbicide treatments for control of leafy spurge (Euphorbia esula L.) In: Leafy spurge control in the Great Plains. GPC 14:69-74. 
Bartz, S.J., B. Landgraf, P.K. Fay, and K. Havstad. 1985. Leafy spurge (Euphorbia esula L.) as a forage component for ewes and lambs. SID Res. Digest, Winter 1985, p. 39-42.

Christensen, F.W., T.H. Hopper, E.A. Helgeson, and E.J. Thompson. 1938. Leafy spurge as a feed for sheep. Proc. Amer. Soc. Anim. Prod. 31:311-316.

Dunn, P.H. 1979. The distribution of leafy spurge (Euphorbia esula L.) and other weedy Euphorbia spp. in the United States. Weed Sci. 27:509-516. Johnston, A., and R.W. Peake. 1960. Effect of selective grazing by sheep on control of leafy spurge (Euphorbia esula L.). J. Range Manage. 12:192-195.

Kingsbury, J.M. 1964. Poisonous plants of the United States and Canada. Prentice-Hall, N.J.
Landgraf, B.K., P.K. Fay, and K.M. Havstad. 1984. Utilization of leafy spurge (Euphorbia esula) by sheep. Weed Sci. 32:348-352.

Lym, R.G., and C.G. Messersmith. 1985. A summary of leafy spurge control with herbicides in North Dakota: 20-year summary. J. Range Manage. 38:149-154.

Lym, R.G., and D.R. Kirby. 1987. Cattle foraging behavior in leafy spurge (Euphorbia esula L.) infested rangeland. Weed Tech. 1:314-318.

Messersmith, C.G., and R.G. Lym. 1983. Distribution and economic impacts of leafy spurge in North Dakota. N.D. Farm Res. 40:8-13.

Pieper, R.D. 1978. Measurement techniques for herbaceous and shrubby vegetation. New Mexico State Univ., Las Cruces, N.M. 